\title{
Pendekatan Kritis Implementasi Akad Wadi'ah pada Perbankan Syariah Indonesia
}

\author{
Mushlih Candrakusuma \\ Program Pasca Sarjana Ekonomi Islam, \\ Sekolah Tinggi Agama Islam Negeri (STAIN), Ponorogo \\ Email: candrakusuma41@gmail.com \\ Mohammad Ghozali \\ Program Pasca Sarjana Ekonomi Islam, \\ Sekolah Tinggi Agama Islam Negeri (STAIN), Ponorogo \\ Email: ghozali.unida@gmail.com
}

\begin{abstract}
As a natural situation, the Islamic banking industry not only have a chance, but also the various problems such as problem on products giro and saving syariah based on wadi'ah. In wadi'ah saving, bank syariah receive trustful saving from the client and distributing it to use it optimally. Actually, the use of trustful saving (wadi'ah) is forbidden, but what is applied in the banking industry is wadi'ah used to any project of business. From this point of view, this kind of application more relevant to qard contract than wadi'ah. The purpose of Islamic law (maqasid al-shari'ah) is to ensure the wealth (hifz al-mal) embodied in the product save deposit box. In save deposit box, wealth entrusted in bank, stored in a special place, that are guarded by the bank. At the level of primary (al-daruriyah), safeguarding the wealth is a basic need for Muslim. So that, the sustainability of safeguarding of wealth should be championed.
\end{abstract}

Keywords: Wadi'ah, Islamic Banking, The Purpose of Islamic Law, Safeguarding the wealth.

\section{Pendahuluan}

$G$ slam adalah agama yang sempurna, karena memiliki syariat yang sangat istimewa yang bersifat universal dan komprehensif. Universal berarti agama yang sesuai untuk 
diterapkan setiap waktu dan tempat. Sedangkan komprehensif berarti Islam mencakup seluruh aspek kehidupan baik ibadah maupun muamalah. Sedangkan yang di maksud dalam bidang muamalah sendiri mempunyai arti yang cukup luas, salah satunya dalam bidang ekonomi dan perbankan. ${ }^{1}$

Salah satu sarana yang mempunyai peran strategis dalam kegiatan perekonomian adalah perbankan. Peran strategis terutama dengan adanya fungsi utama perbankan sebagai suatu lembaga yang dapat menghimpun dan menyalurkan dana masyarakat secara efektif dan efesien (financial intermediary). Bank syariah pada awalnya dikembangkan sebagai suatu respon dari kelompok ekonom dan praktisi perbankan Muslim yang berupaya mengakomodasi usulan berbagai pihak yang menginginkan keberadaan jasa transaksi keuangan yang sesuai dengan syariah Islam yang melarang adanya praktik riba, kegiatan maysir (perjudian), gharar (ketidakjelasan) serta keharusan penyaluran dana investasi pada kegiatan usaha yang etis dan halal secara syariah. ${ }^{2}$

Lembaga perbankan syariah di Indonesia telah diatur dalam undang-undang, yaitu Undang-Undang nomor 10 tahun 1998 tentang perubahan Undang-undang nomor 7 tahun tahun 1992 tentang perbankan. Hingga kini terdapat banyak institusi bank syariah di Indonesia. Keberadaan lembaga keuangan dalam Islam adalah vital karena kegiatan bisnis dan roda ekonomi tidak akan berjalan tanpanya. Tujuan utama dari pendirian lembaga keuangan syariah ini tiada lain adalah sebagai upaya kaum muslimin untuk mendasari segenap aspek kehidupan ekonominya berlandaskan al-Qur'an dan al-Sunnah. ${ }^{3}$

Kendatipun perbankan syariah melalui program-programnya telah mensosialisasikan produk syariah ke masyarakat umum, namun masih ada sebagian masyarakat yang belum memahami beberapa produk syariah, apabila dikaji tentang manfaatnya, semua produk syariah tentunya mempunyai fungsi dan perannya masingmasing dalam kehidupan ekonomi umat. Pada fase perkembangan

${ }^{1}$ Adiwarman Azwar Karim, Sejarah Pemikiran Ekonomi Islam (Jakarta: Rajawali Press, 2010), 5

${ }^{2}$ Adrian Sutedi, Perbankan Syariah: Tinjauan dan Beberapa Segi Hukum (Bogor: Ghalia Indonesia, 2009), 3. Adiwarwan Azwar Karim, Bank Islam: Analisis Fiqih dan Keuangan (Jakarta: Rajawali Press, 2006), 203 2008), 11

${ }^{3}$ Hirsanuddin, Hukum Perbankan Syariah di Indonesia (Yogyakarta: Genta Press, 
saat ini, perbankan syariah tidak hanya memiliki peluang, melainkan juga berbagai permasalahan. Nasabah dan masyarakat secara umum masih melihat bank syariah sama dengan bank konvensional karena margin yang harus dibayar oleh nasabah tak kalah tinggi dengan bunga. ${ }^{4} \mathrm{Hal}$-hal diatas, merupakan titik lemah perbankan syariah yang menjadi prioritas pikiran kita bersama. Padahal kunci kesuksesan perbankan syariah sangat tergantung dengan tingkat kepercayaan publik terhadap kekuatan financial bank yang bersangkutan.

Untuk meraih kepercayaan tersebut haruslah diraih dengan tingkat kualitas dan kuantitas informasi yang diberikan kepada publik. Bank syariah harus mampu meyakinkan publik bahwa ia memiliki kemampuan dan kapasitas di dalam mencapai tujuantujuan financial maupun tujuan syariat Islam. Berkaitan dengan itu, produk-produk bank syariah pun tak terhindar dari permasalahan. Di dalam prakteknya, terdapat temuan-temuan yang bisa jadi akan mengurangi tingkat keparcayan publik, apabila dibiarkan berlanjut tanpa ada tindakan dari bank syariah. Selain itu, dalam perspektif syariah pun perlu kiranya untuk ditinjau ulang implementasi akad-akad yang ada, sehingga tidak merugikan kedua belah pihak baik pihak bank maupun nasabah.

Dalam implementasinya bank syariah menerapkan prinsip yang disebut dengan wadi'ah yad al-amanah dan wadi'ah yad aldamanah, apabila dianalisis dalam literatur fikih klasik akan sulit diketemukan Terkait dengan kedua produk tersebut. Dalam pelaksanaannya perbankan syariah lebih cenderung menerapkan prinsip akad wadi'ah yad al-damanah. Dengan demikian, perlu dilakukan kajian secara mendalam, yang secara khusus berusaha menjawab dua hal; pertama, apakah praktek wadi'ah tersebut sudah mengacu pada maksud-maksud diterapkannya syariah (maqasid al-shari'ah) yaitu menjaga harta?. Kedua, apakah praktik wadi'ah pada perbankan syariah sesuai dengan prinsip dan ketentuan akad wadi'ah dalam fiqih Islam?.

\section{Definisi Wadi'ah}

Wadi'ah berasal dari akar kata wada'a, yang berarti meninggalkan dan meletakkan atau titipan. Sesuatu yang dititipkan

${ }^{4}$ Gemala Dewi, Aspek-Aspek Hukum Dalam Perbankan dan Perasuransian Syariah di Indonesia (Jakarta: Kencana, 2007), 14 
oleh seseorang kepada orang lain untuk dijaga dinamakan wadi'ah. Ulama Hanafiyah mendefinisikan wadi'ah sebagai upaya mengikut sertakan orang lain dalam memelihara dengan ungkapan yang jelas maupun isyarat. Sedangkan menurut ulama Syafi'iyah dan Malikiyah yaitu mewakilkan orang lain untuk memelihara harta tertentu dengan cara tertentu. ${ }^{5}$

Berdasarkan definisi diatas, dapat disimpulkan bahwa wadi'ah merupakan suatu akad antara dua orang (pihak) di mana pihak yang pertama menyerahkan tugas dan wewenang untuk menjaga barang yang dimilikinya kepada pihak lain tanpa imbalan. Barang yang diserahkan merupakan amanah yang harus dijaga dengan baik. ${ }^{6}$ Sementara itu menurut menurut UU No. 21 tentang Perbankan Syariah yang dimaksud dengan akad wadi'ah adalah akad penitipan barang atau uang antara pihak yang mempunyai barang atau uang dan pihak yang diberi kepercayaan dengan tujuan untuk menjaga keselamatan, keamanan, serta keutuhan barang atau uang. ${ }^{7}$ Wadi'ah juga dapat dipahami sebagai titipan murni dari satu pihak kepihak yang lain, baik individu maupun badan hukum, yang harus dijaga dan dikembalikan kapan saja si penitip menghendakinya. ${ }^{8}$

Landasan wadi'ah terdapat dalam al-Qur'an (QS. An-Nisa' [4]: $58)$,

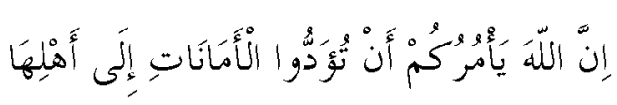

"Sesungguhnya Allah menyuruh kamu untuk menyampaikan amanat (titipan), kepada yang berhak menerimanya"

Dalam ayat tersebut dijelaskan bahwa wadi'ah merupakan amanah yang harus dijaga dan dipelihara, dan apabila diminta oleh pemiliknya maka ia wajib mengembalikannya. Wadi'ah pada prinsipnya adalah akad tabarru', pihak yang menerima titipan atau barang atau uang membantu pihak yang menitipkan. ${ }^{9}$

Akad wadi'ah dianggap sah apabila memenuhi rukun dan syarat yang telah ditentukan. Menurut mayoritas ulama rukun wadi'ah ada empat, yaitu: benda yang dititipkan (al-'ain al-

\footnotetext{
${ }^{5}$ Ahmad Wardi Muslich, Figh Muamalat (Jakarta: Amzah, 2013), 456.

${ }^{6}$ Ibid., 457.

${ }^{7}$ http://www.bi.go.id/id/tentang-bi/uu-bi/Documents/UU 2108 Syariah.pdf, diakses Sabtu 16 April 2016, jam 16.30 WIB.

${ }^{8}$ Hulwati, Ekonomi Islam (Jakarta: Ciputat Press, 2006), 106.

${ }^{9}$ Abdullah Saeed, Bank Islam dan Bunga: Studi Kritis dan Interprestasi Kontemporer tentang Riba dan Bunga (Yogyakarta: Pustaka Pelajar, 2003), 72.
} 
muda'ah), orang yang menitipkan (al-muwaddi'), orang yang dititipi (al-mustawda') dan ijab qabul. ${ }^{10}$ Barang titipan menjadi kemuliaan menjadi orang yang menerima barang titipan, karena hal tersebut mengandung nilai ibadah dan pahala, disamping mempunyai nilai sosial yang tinggi. Akan tetapi agar titipan tersebut tidak akan menimbulkan masalah dikemudian hari, maka disyaratkan agar: ${ }^{11}$

1) Barang titipan tidak memberatkan dirinya maupun keluarganya

2) Tidak memungut biaya pemeliharaan

3) Kalau sudah sampai waktunya diambil atau disampaikan kepada yang berhak.

Dengan demikian apabila barang titipan itu mengalami kerusakan akibat kelalaian orang yang menerimanya, maka ia wajib menggantikannya. Adapun yang termasuk dalam kriteria kelalaian antara lain: ${ }^{12}$

1) Orang yang dipercaya menyerahakan titipan tersebut kepada orang lain tanpa sepengetahuan yang memilikinya

2) Barang titipan dipergunakan atau dibawa pergi sehingga rusak atau hilang

3) Menyia-nyiakan barang titipan

4) Berkhianat, yaitu ketika barang titipan diminta tidak diserahkan tanpa sebab yang jelas

5) Lalai dalam memelihara barang titipan

6) Ketika si penerima titipan sakit atau meninggal, namun tidak berwasiat kepada ahli warisnya, sehingga mengakibatkan barang rusak dan hilang

Dalam kajian fikih, hukum menerima wadi'ah atau barang titipan ada lima, yaitu: ${ }^{13}$

1) Sunnah, bagi orang yang percaya kepada dirinya bahwa dia sanggup menjaga titipan yang diserahkan kepadanya

2) Wajib, hukum menerima benda titipan dapat berhukum wajib jika tidak ada orang jujur dan layak selain dirinya

3) Mubah, hukum menerima benda titipan boleh jika seseorang mengatakan kepada si penitip bahwa dirinya khawatir akan berkhianat namun si pentitip yakin dan tetap mempercayai bahwa orang tersebut dapat diberikan amanah

\footnotetext{
${ }^{10}$ Muslich, Figh Muamalat, 459

${ }^{11}$ Zainul Arifin, Memahami Bank Syariah (Jakarta: Pustaka Alvabet, 1999), 48

${ }^{12}$ Ibid.

${ }^{13}$ Sulaiman Rasjid, Fiqh Islam (Bandung: Sinar Baru, 1994), 330
} 
4) Makruh, yaitu bagi orang yang dapat menjaganya, tetapi ia tidak percaya kepada dirinya sendiri. Dan boleh jadi, kemudian hari hal itu akan menyebabkan dia berkhianat terhadap barang yang dititipkan kepadanya

5) Haram, apabila si penerima titipan tidak sanggup menjaga barang yang dititipkan sebagaiman mestinya, karena seolaholah ia membukakan pintu untuk kerusakan atau lenyapnya barang yang dititipkan itu.

\section{Implementasi Akad Wadi'ah pada Perbankan Syari'ah}

Implementasi akad wadi'ah pada bank syariah dapat dibagi menjadi dua jenis, pertama, wadi'ah yad al-amanah. Kedua, wadi'ah yad al-damanah. Pada awalnya, akad wadi'ah muncul dalam bentuk yad al-amanah dan kemudian berkembang menjadi yad aldamanah. Akad wadi'ah yad al-dhamanah ini pada akhirnya banyak dipergunakan dalam produk-produk perbankan. ${ }^{14}$

\subsection{Wadi'ah yad al-Amanah}

Akad ini merupakan bagian dari akad wadi'ah dimana pihak penyimpan sebagai penerima kepercayaan tidak diharuskan bertanggung jawab jika dalam penitipan terjadi kehilangan ataupun kerusakan pada barang, sepanjang bukan akibat dari kelalaian atau kecerobohan dalam memelihara barang titipan. Biaya penitipan boleh dibebankan kepada pihak penitip sebagai kompensasi atas tanggung jawab pemeliharaan.

Dengan prinsip ini, pihak penyimpan tidak boleh menggunakan atau memanfaatkan barang yang dititipkan, melainkan hanya menjaganya. Barang titipan tidak boleh dicampuradukkan dengan barang lain. ${ }^{15}$ Aplikasi perbankan yang memungkinkan untuk menerapkan jenis akad ini adalah save deposit box, yang mana nasabah sebagai penitip (al-muwaddi') serta bank selaku penyimpan (al-mustawda'). Pihak bank berdasar akad ijarah, dapat membebankan biaya sewa atas tempat penyimpanan yang digunakan untuk menyimpan barang titipan. ${ }^{16}$

\footnotetext{
${ }^{14}$ Ascarya, Akad \& Produk Bank Syariah (Jakarta: Rajawali Pers, 2013), 42

${ }^{15}$ Ascarya, Akad \& Produk Bank Syariah, 43

${ }^{16}$ Muhammad Syafii Antonio, Bank Syari'ah dari Teori ke Praktik (Jakarta: Gema Insani, 2007), 148
} 


\subsection{Wadiah yad al-Dhamanah}

Merupakan jenis akad wadi'ah dimana pihak penyimpan bertanggung jawab atas segala kerusakan atau kehilangan yang terjadi pada barang. Pihak penyimpan telah mendapatkan izin dari pihak penitip untuk menggunakan barang atau aset yang dititipkan tersebut untuk aktivitas perekonomian tertentu, dengan catatan pihak penyimpan akan mengembalikan barang yang dititipkan secara utuh pada saat penyimpan mengambilnya. Dengan demikian, penyimpan boleh mencampur barang atau aset penitip dengan aset yang lain, dan kemudian digunakan untuk tujuan produktif. Penyimpan juga diperbolehkan untuk memberikan bonus kepada pemilik aset tanpa akad perjanjian yang mengikat sebelumnya. ${ }^{17}$

Aplikasi perbankan yang sesuai dengan jenis akad ini adalah tabungan dan giro. Dalam hal ini tabungan wadi'ah (savings account) dan giro wadi'ah (current account) merupakan sumber modal dalam perbakan syariah. Bank syariah menerima titipan amanah dalam menyimpan dan menyalurkan dana umat agar dapat bermanfaat secara optimal. Pemberian bonus dilakukan sebagai upaya merangsang semangat masyarakat dalam menabung dan sekaligus sebagai indikator kesehatan bank. Pemberian bonus tidak dilarang dengan catatan tidak disyaratkan sebelumnya dan secara jumlah tidak ditetapkan dalam nominal atau prosentase. ${ }^{18}$

Berdasarkan fatwa Dewan Syari'ah Nasional (DSN) No: 01/ DSN MUI/IV/2000, dinyatakan bahwa giro yang dibenarkan secara syariah, yaitu giro yang berdasarkan prinsip mudharabah dan wadi'ah. ${ }^{19}$ Demikian juga tabungan dengan produk wadi'ah, dapat dibenarkan berdasarkan fatwa DSN No: 02//DSN-MUI/IV/2000, menyatakan bahwa tabungan yang dibenarkan, yaitu tabungan yang berdasarkan prinsip mudarabah dan wadi'ah.$^{20}$

Tabungan dan giro wadi'ah hendaklah memenuhi beberapa ketentuan umum, di antaranya tabungan merupakan tabungan

${ }^{17}$ Ascarya, Akad E Produk, 44.

${ }^{18}$ Karnaen dan Syafii Antonio, Apa dan Bagaimana Bank Islam (Yogyakarta: Dana Bakti Wakaf, 1992), 104

${ }^{19} \mathrm{http}: / /$ www.dsnmui.or.id/index.php?mact=News, cntnt01, detail, 0\&cntnt01 articleid $=2 \&$ cntnt01 origid $=59 \&$ cntnt01detailtemplate $=$ Fatwa\& cntnt01 returnid $=61$, diakses Sabtu 16 April 2016, jam 17.00 WIB.

${ }^{20} \mathrm{http}: / /$ www.dsnmui.or.id/index.php?mact=News, cntnt01, detail, 0\&cntnt01 articleid=3\&cntnt01 origid $=59 \&$ cntnt01detailtemplate=Fatwa\&cntnt01 returnid=61, diakses Sabtu 16 April 2016, jam 17.00 WIB. 
yang bersifat titipan murni yang harus dijaga dan dikembalikan setiap saat (on call) sesuai dengan kehendak pemilik harta. Keuntungan atau kerugian dari penyaluran dana atau pemanfaatan barang menjadi milik atau tanggungan bank, sedangkan nasabah selaku penitip tidak dijanjikan imbalan dan tidak menanggung kerugian. Bank dimungkinkan memberikan bonus kepada pemilik harta sebagai sebuah insentif selama tidak diperjanjikan dalam akad pembukaan rekening. ${ }^{21}$

\section{Maqashid Syariah terhadap Keterjagaan Harta}

Tujuan hukum Islam sejalan dengan tujuan hidup manusia serta potensi yang ada dalam dirinya dan potensi yang datang dari luar dirinya, yakni kebahagiaan hidup baik di dunia maupun di akhirat. Tujuan ini dapat dicapai dengan cara mengambil segala hal yang memiliki kemaslahatan dan menolak segala hal yang merusak dalam rangka menuju keridhoan Allah (maqshid syariah).

Menurut al-Shatibi, kemaslahatan itu dapat terwujud dengan terjaganya lima unsur pokok. Kelima unsur pokok itu adalah memelihara agama (hifz al-din), memelihara jiwa (hifz alnafs), memelihara akal (hifz al-'aql), memelihara keturunan (hifz al-nasl), dan memelihara harta (hifz al-mal). ${ }^{22}$ Dalam usaha mewujudkan dan memelihara lima unsur pokok itu al-Shatibi mengemukakan tiga peringkat maqasid al-shari'ah (tujuan syariat), yaitu; pertama, tujuan primer (maqasid al-daruriyah), kedua adalah tujuan sekunder (maqasid al-hajjiyah), dan ketiga tujuan tersier (maqasid al-tahsiniyah). Atas dasar ini hukum Islam dikembangkan, khususnya masalah muamalah baik ekonomi, hukum pidana, perdata, ketatanegaraan, politik hukum, maupun yang lainnya. ${ }^{23}$

Terkait dinamika praktik perbankan syariah, penting untuk dilakukan kajian dari aspek kesesuaian akad-akad yang diterapkan dengan tujuan syariat Islam. Tidak terkecuali dengan keterjagaan barang titipan di perbankan syariah. Sebagaimana yang telah diljelaskan, aplikasi perbankan dari akad wadi'ah meliputi: save deposit box, tabungan wadi'ah dan giro wadi'ah.

\footnotetext{
${ }^{21}$ Karim, Bank Islam, 297-298

${ }^{22}$ Kutbuddin Aibak, Metodologi Pembaharuan Hukum Islam (Yogyakarta: Pustaka Pelajar, 2008), 17

${ }^{23}$ Duski Ibrahim, Metode Penetapan Hukum Islam: Membongkar Konsep Al-Istiqra' Al-Ma'nawi Asy-Syatibi (Jogjakarta: Ar-Ruzzmedia, 2008), 98
} 
Dalam save deposit box, uang atau harta yang dititipkan ke bank disimpan dalam suatu tempat penyimpanan khusus yang dijaga oleh pihak bank. Pihak bank dapat menarik biaya sewa dari nasabah atas box yang digunakan untuk menyimpan uang atau harta dari nasabah. Kotak penyimpanan umumnya ditempatkan pada ruangan yang dirancang secara khusus dari bahan baja, tahan bongkar dan tahan api untuk keamanan harta yang disimpan. Keamanan harta menjadi hal yang tidak ternilai harganya dalam kondisi ketidakpastian. Dengan demikian penerapan akad wadi'ah dan upaya bank untuk menjaga barang titipan dalam bentuk save deposit box, sudah merupakan bagian dari pemeliharaan harta (hifz al-mal) untuk mencapai tujuan-tujuan syariat. Pada level primer (al-daruriyah) dari tujuan-tujuan syariat, dapat dipahami bersama bahwa memelihara harta, baik dalam bentuk uang, barang berharga seperti logam mulia, perhiasan, sertifikat dan lainnya merupakan sesuatu yang pokok, sehingga harus diperjuangkan keberlangsungan pemeliharaan untuk keterjagaan harta-harta tersebut. Sedangkan pada level sekunder (al-hajjiyah), diperlukan sarana dan prasarana yang dapat digunakan untuk menjaga keberlangsungan pemeliharaannya, dan save deposit box merupakan salah satu sarana dari bank yang memfasilitasi untuk menjaga pemeliharaan terhadap harta (hifz al-mal).

Selanjutnya dalam tabungan dan giro, akad yang digunakan adalah wadi'ah yad al-dhamanah, sehingga dalam praktiknya harta yang dititipkan dimanfaatkan oleh pihak bank untuk melakukan aktivitas ekonomi produktif. Meski demikian tabungan dan giro wadi'ah dapat dikembalikan setiap saat (on call) sesuai dengan kehendak pemilik harta. Sehingga keterjagaan harta pada tabungan dan giro bukan terletak pada pemeliharaan secara fisik, akan tetapi keterjagaan atas jaminan nilai harta yang dititipkan pada bank syariah. Bank selaku pihak yang dititipi bertanggung jawab secara penuh atas resiko yang terjadi.

\section{Analisa Fiqh Muamalah terhadap Penerapan Akad Wadi'ah}

Pada awalnya, wadi'ah muncul dalam bentuk yad alamanah yang kemudian dalam perkembangannya memunculkan yad al-damanah. Dalam akad wadi'ah yad al-amanah pihak bank syariah tidak boleh menggunakan atau memanfaatkan barang yang dititipkan. Sedangkan dalam akad wadi'ah yad al-dhamanah pihak 
bank syariah telah mendapatkan izin dari nasabah untuk menggunakan harta yang dititipkan untuk aktivitas perekonomian tertentu, dengan catatan bahwa pihak bank akan mengembalikan barang yang dititipkan secara utuh pada saat nasabah menghendaki.

Terkait dengan kedua jenis akad wadi'ah tersebut, dalam pelaksanaannya perbankkan syariah lebih menerapkan akad wadi'ah yad al-dhamanah daripada akad wadi'ah yad al-amanah. Sehingga lebih banyak harta wadi'ah (titipan) yang digunakan untuk tujuan produktif daripada harta yang benar-benar tersimpan, padahal uang tersebut sewaktu-waktu (on call) bisa ditarik oleh nasabah. Sehingga sangat mungkin terjadi problem disaat terdapat sejumlah nasabah yang menarik uang titipan dalam jumlah besar secara bersama-sama, sedangkan uang titipan tersebut dalam waktu bersamaan banyak yang diinvestasikan.

Dalam praktiknya, penerapan wadi'ah yad al-dhamanah juga terkesan pihak bank ingin mencari untung tanpa adanya tanggungan untuk memberikan bagi hasil. Karena di dalam praktiknya baik produk giro wadi'ah ataupun tabungan wadi'ah, pihak bank meminta pihak nasabah memberikan kewenangan kepada pihak bank untuk mengelola asetnya, dan bank memiliki hak penuh atas hasil yang diperoleh dari pemanfaatan titipan nasabah. Dengan kata lain, bank tidak dikenai tanggungjawab (kewajiban) membagi hasilnya.

Secara komprehensif, pembagian akad wadi'ah menjadi wadi'ah yad al-amanah dan wadi'ah yad al-dhamanah tidak ditemukan dalam literatur fikih klasik. Bahkan, apabila dibedah secara prinsip, akad tersebut khususnya wadi'ah yad al-dhamanah cenderung memaksakan diri mempergunakan dana titipan untuk bisa digunakan pada kegiatan produktif yang diinginkan pihak bank. Padahal jika dikembalikan kepada definisinya, wadi'ah merupakan suatu akad titipan murni antara dua pihak, di mana pihak yang pertama menyerahkan tugas, wewenang dan kepercayaan kepada pihak lain untuk menjaga keselamatan, keamanan, serta keutuhan barang atau uang yang dititipkan. Jadi, dana yang ditipkan sejatinya untuk dijaga, bukan untuk dimanfaatkan ataupun diinvestasikan. Secara prinsip dalam akad wadi'ah, pemanfaatan suatu titipan dalam bentuk apapun hukumnya terlarang. Apabila terdapat unsur penggunaan oleh pihak yang dititipi (bank), maka akad yang diterapkan menjadi 
berubah. Di dalam istilah fikih, yang demikian dikatakan sebagai akad qard (hutang-piutang).

Dengan demikian akan bisa menjadi alternatif pengembangan produk baru dalam perbankan syariah yang dapat disitilahkan dengan tabungan qard dan giro qard, sebagai solusi atas ketidakjelasan penerapan akad wadi'ah yang tidak sesuai dengan prinsipprinsip wadi'ah itu sendiri.

\section{Kesimpulan}

Wadi'ah secara etimologi berasal dari akar kata wada'a, yang artinya meninggalkan atau meletakkan atau titipan. Sedangkan menurut istilah wadi'ah adalah suatu akad antara dua orang (pihak) di mana pihak yang pertama menyerahkan tugas dan wewenang untuk menjaga barang yang dimilikinya kepada pihak lain tanpa imbalan. Wadi'ah juga dapat dipahami sebagai titipan murni dari satu pihak kepihak yang lain, baik individu maupun badan hukum, yang harus dijaga dan dikembalikan kapan saja si penitip menghendakinya. Sementara itu menurut menurut UU No. 21 tentang Perbankan Syariah yang dimaksud dengan akad wadi'ah adalah akad penitipan barang atau uang antara pihak yang mempunyai barang atau uang dan pihak yang diberi kepercayaan dengan tujuan untuk menjaga keselamatan, keamanan, serta keutuhan barang atau uang.

Berdasarkan fatwa DSN No: 01/DSN MUI/IV/2000, menetapkan bahwa giro yang dibenarkan secara syariah, yaitu giro yang berdasarkan prinsip mudharabah dan wadi'ah. Demikian juga tabungan dengan produk wadi'ah, dapat dibenarkan berdasarkan fatwa DSN No: 02//DSN-MUI/IV/2000, menyatakan bahwa tabungan yang dibenarkan, yaitu tabungan yang berdasarkan prinsip mudharabah dan wadi'ah. Penerapan akad wadi'ah dan upaya bank untuk menjaga barang titipan dalam bentuk save deposit box, sudah merupakan bagian dari pemeliharaan harta (hifz al-mal) untuk mencapai tujuan-tujuan syariat. Pada level primer (al-daruriyah), dapat dipahami bahwa memelihara harta merupakan sesuatu yang pokok, sehingga harus diperjuangkan keberlangsungan pemeliharaan untuk keterjagaan harta-harta tersebut. Sedangkan pada level sekunder (al-hajjiyah), save deposit box merupakan salah satu sarana dari bank yang memfasilitasi untuk menjaga pemeliharaan terhadap harta (hifz al-mal). 
Dalam pelaksanaannya perbankkan syariah lebih menerapkan akad wadi'ah yad al-dhamanah daripada akad wadi'ah yad alamanah. Akad tersebut cenderung memaksakan diri mempergunakan dana titipan untuk bisa digunakan pada kegiatan produktif yang diinginkan pihak bank. Secara prinsip, dalam wadi'ah pemanfaatan suatu titipan dalam bentuk apapun hukumnya terlarang, karena apabila telah ada unsur penggunaan oleh pihak yang dititipi (bank) unuk dimanfaatkan maka akadnya pun berubah menjadi qard (hutang-piutang). Akad wadi'ah yang ada di perbankan syariah bukanlah akad wadi'ah yang dijelaskan dalam kitab-kitab fikih. Wadi'ah yang diterapkan di perbankan syariah saat ini, lebih relevan dengan akad qard (hutang-piutang). Apa yang diterapkan oleh perbankan syariah sejatinya ialah akad qard yang kemudian disebut dengan akad wadi'ah, yang tepatnya mengacu pada wadi'ah yad al-dhamanah.

\section{Daftar Pustaka}

Aibak, Kutbuddin. 2008.Metodologi Pembaharuan Hukum Islam. Yogyakarta. Pustaka Pelajar.

Antonio, Muhammad Syafii. 2007. Bank Syari'ah dari Teori ke Praktik. Jakarta. Gema Insani.

Antonio, Syafii dan Karnaen. 1992. Apa dan Bagaimana Bank Islam. Yogyakarta. Dana Bakti Wakaf.

Arifin, Zainul. 1999. Memahami Bank Syariah. Jakarta. Pustaka Alvabet.

Ascarya. 2013. Akad \& Produk Bank Syariah. Jakarta. Rajawali Pers. Dewi, Gemala. 2007. Aspek-Aspek Hukum Dalam Perbankan dan Perasuransian Syariah di Indonesia. Jakarta. Kencana.

Haroen, Nasrun. 2000. Figh Mu'amalah. Gaya Media Pratama. Jakarta.

Hirsanuddin. 2008. Hukum Perbankan Syariah di Indonesia. Yogyakarta. Genta Press.

Hulwati. 2006. Ekonomi Islam. Jakarta. Ciputat Press.

Ibrahim, Duski. 2008. Metode Penetapan Hukum Islam: Membongkar Konsep Al-Istiqra' Al-Ma'nawi Asy-Syatibi. Jogjakarta. ArRuzzmedia.

Karim, Adiwarman Azwar. 2010. Sejarah Pemikiran Ekonomi Islam. Jakarta. Rajawali Press.

2006. Bank Islam: Analisis Fiqih dan Keuangan. Jakarta. Rajawali Press. 
Muslich, Ahmad Wardi. 2013. Figh Muamalat. Jakarta. Amzah. Rasjid, Sulaiman. 1994. Figh Islam. Bandung. Sinar Baru.

Rivai, Veithzal. dkk. 2007. Bank and Financial Institution Management Conventional \& Sharia Syistem. Jakarta. Raja Grafindo Persada.

Saeed, Abdullah. 2003. Bank Islam dan Bunga: Studi Kritis dan Interprestasi Kontemporer tentang Riba dan Bunga. Yogyakarta. Pustaka Pelajar.

Sutedi, Adrian. 2009. Perbankan Syariah: Tinjauan dan Beberapa Segi Hukum. Bogor. Ghalia Indonesia. 